\title{
焉枺研究 VI
}

\section{肛門疾患術後におけりる経肛門的 超音波検査の有用性}

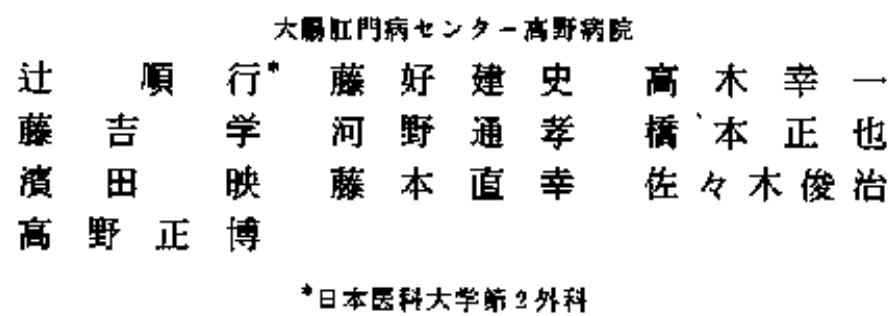

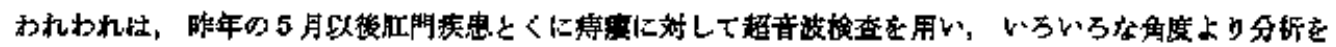

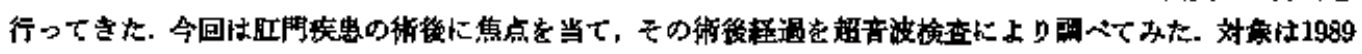

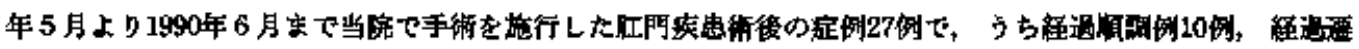

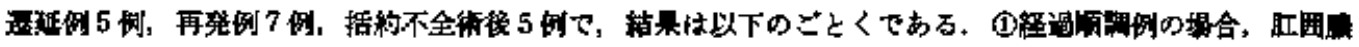

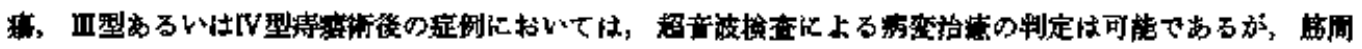

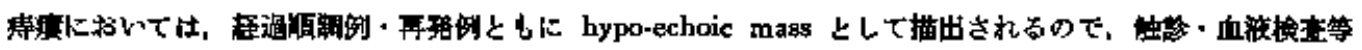

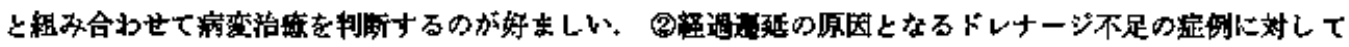

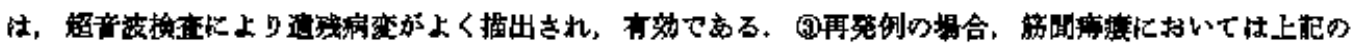

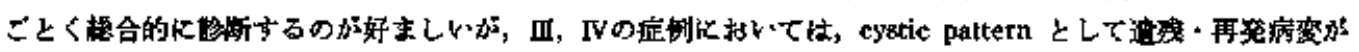

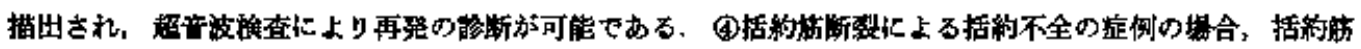

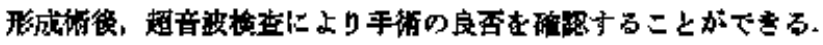

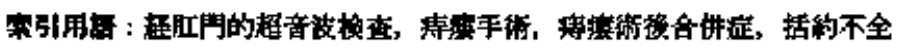

\section{はじめに}

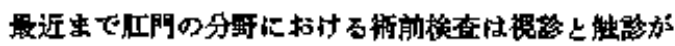

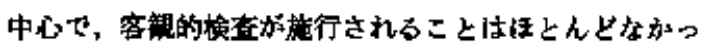
た. しかしここ数年の周に，䀴門疾急に対してし客的

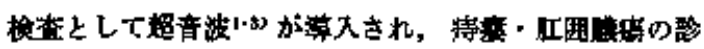
断煌比的客易となった。

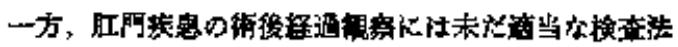

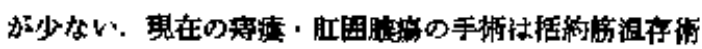

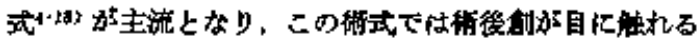

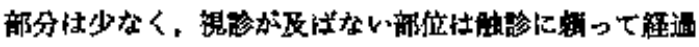
齐道っているのか現状である。

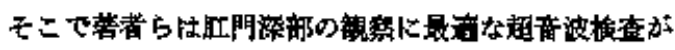

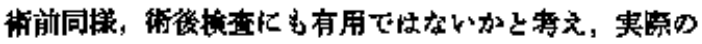
定例に店用してみた。

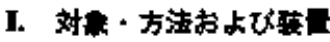

対象璐例は，1989年5月より1990年6月までの当院で

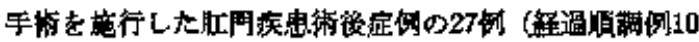

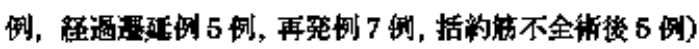
である.

捈查方法怯、からかしめダリセりン浣胆（100ml）を

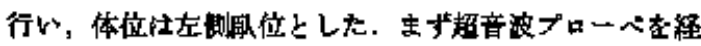

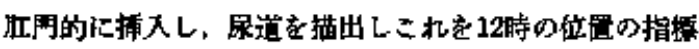

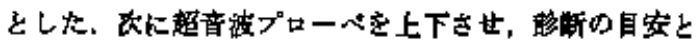

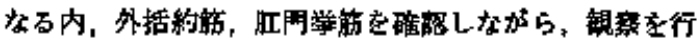
$2 k$.

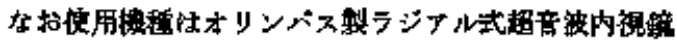

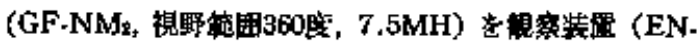
Mo) k接䗷して使用した. 


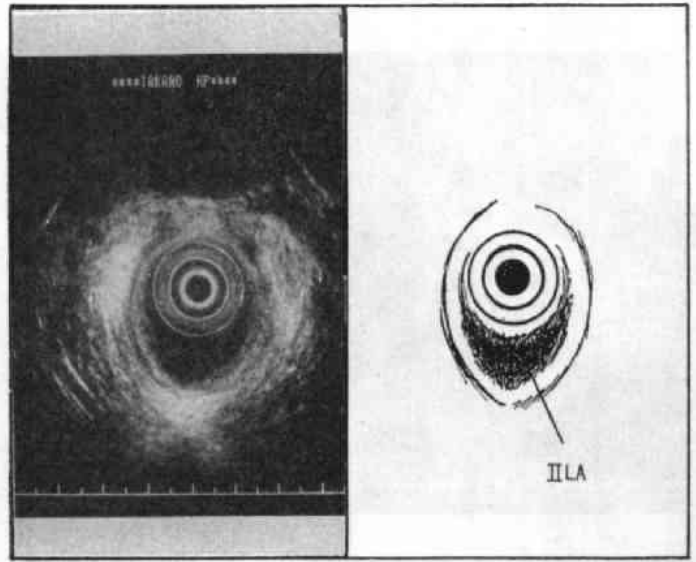

図 1 症例 1 (赫前)

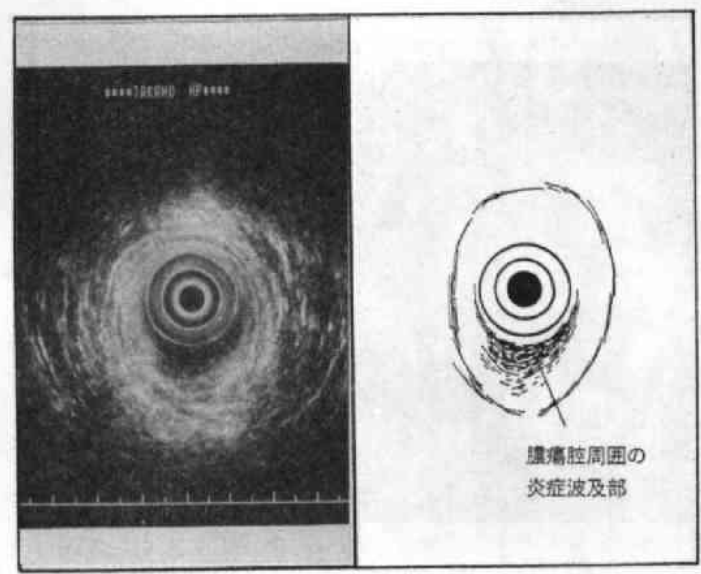

図 2 症例 1 (術直後)

\section{II. 結 果}

\section{1. 肛用澧㾇・痔瘻術後の経過順調例}

肚囲膿瘍の術前の超音波画像は cystic pattern として 描出される。術後は膿視腔の膿汁が排出されるため cystic pattern b消失し, 街直後は膿掝腔周囲の炎症波及 部が超音波画像上, hypo-echoic に描出される.しかし 病変の治濩に従って, hypo-echoic な部分b消失し, や がて病変部は韶められなくなる.

痔瘦の場合は, 術前は hypo-echoic mass として描出 され，診断は容易であるが，術後は肛囲膿癔症例と異な り, 治癄後も病変治癔部が術前や術後再発例と同㥞に, 依然として hypo-echoic mass として描出されるため, 治答の判定に難沾する.

症例 1 ：低位筋間膿㾴 II LA

術前 6 時の方向に cystic pattern を認め, 典型的

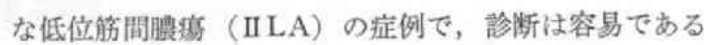

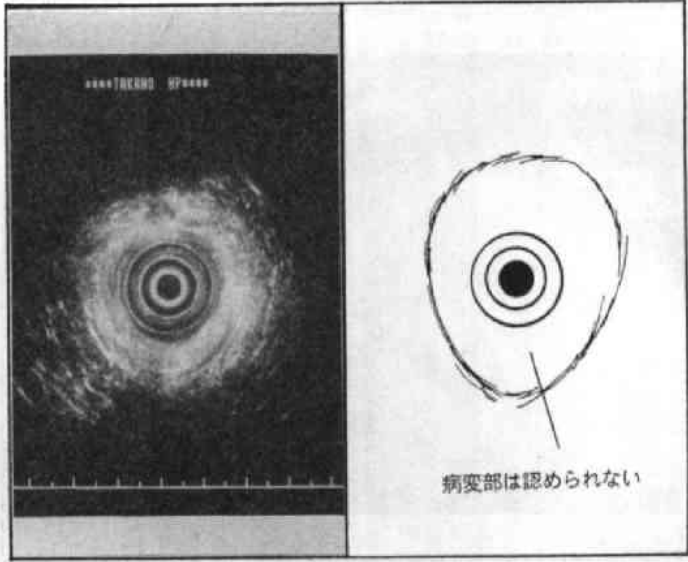

図 3 定例 1 (術後 1 力月)

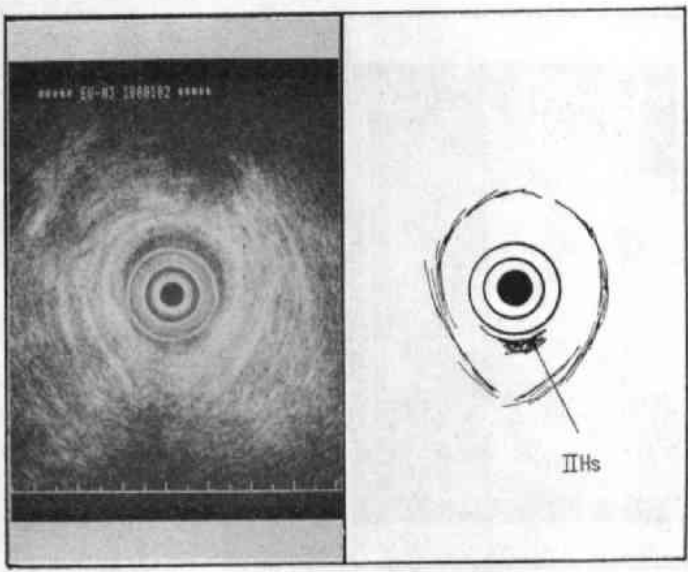

図 4 症例 2 (断前)

(図 1).

術直後 㮛治術㨁後の超音波画像であるが, 膿癔は排 出されているため, cystic pattern は消失している。し かし膿㾤腔周囲の炎症波及部が hypo-echoic に描出さ れている(図 2).

術後 1 力月 根治術後 1 力月目の超音波画像で, 痔獎 の症例と異なり，超音波㭘查を施行しても病変部が認め られなくなっている(図3).

症例 2 : 高位低位笳間帱掼 II Hs II Ls

術前 超音波画像上, 6 時の方向に hypo-echoic mass を認め，典型的な箭間病変の超音波画像を示している. クリプトフックを crypt にかけ，検査を施行すると dentate line の上下に hypo-echoic mass を䀔め, 診断

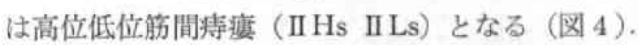

術後 1 力月 lay open 街後 1 力月の超音波画像で, 内 眼的にはわずかに手術の撚痕を認めるだけとなっている か゚，超音波検查を施行すると病変治獶部が術前の超音波 


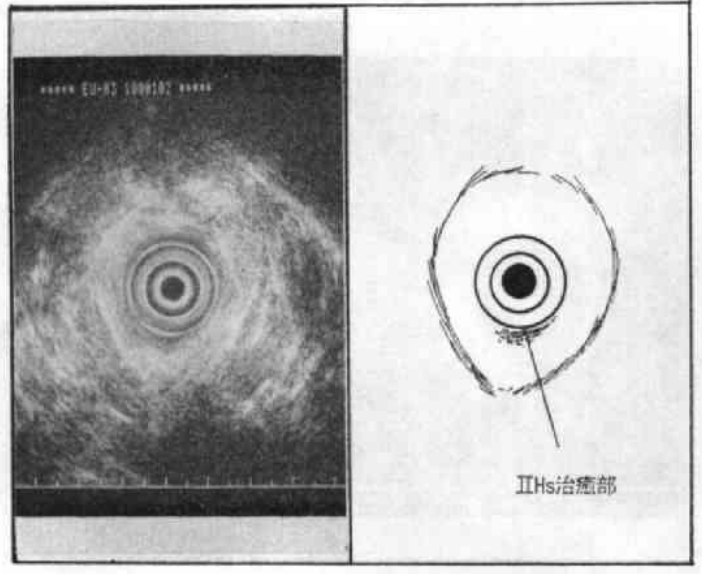

图 5 症例 2 (術後 1 力月)

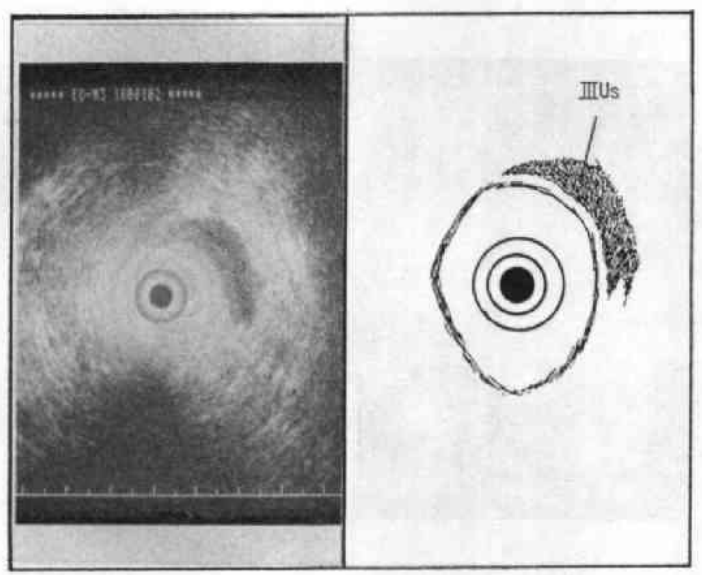

圆 6 症例 3 (街前)

画像と同様に hypo-echoic mass として描出され, 治瘦 の診断に難渋する(図 5).

症例 $3:$ 坐骨直得䆟痔瘦 $\mathrm{mU}$ Us

術前 超音波画像上，12時から4時にかけて外括約筋 の外側に hypo-echoic mass を認め, 診断は前方の坐骨 直腸窝疛痤（IIIUs）となる（図6).

術後 1 力月 括約勋温存術式 1 力月目で, 術後順調に

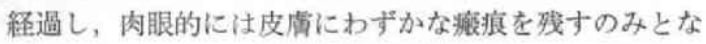
っている、しかし超音波検查を施行すると術前と同様に 病変治癒部が hypo-echoic に描出される (図 7 ).

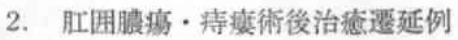

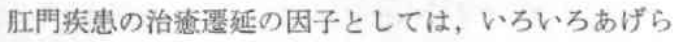
れているが，その中でとくに超音波検查が猃断能力を有 する因子は，坐骨㨁腸䆚病変（IIIB）等における馬蹄形 の病変部分のドレナージ不十分の症例などに対してであ る.これらの症例においては治瘜遷延の原因となるドレ ナージ不十分の病変部が hypo-echoic mass として描出

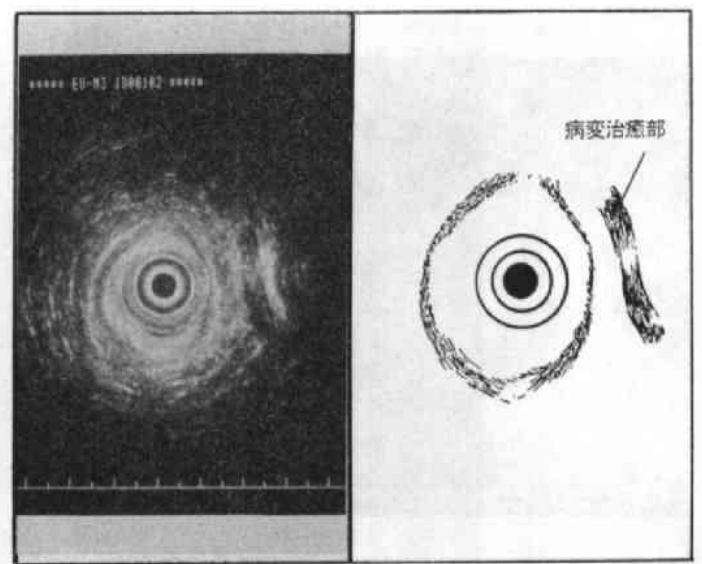

図 7 症例 3 (街後 1 力月)

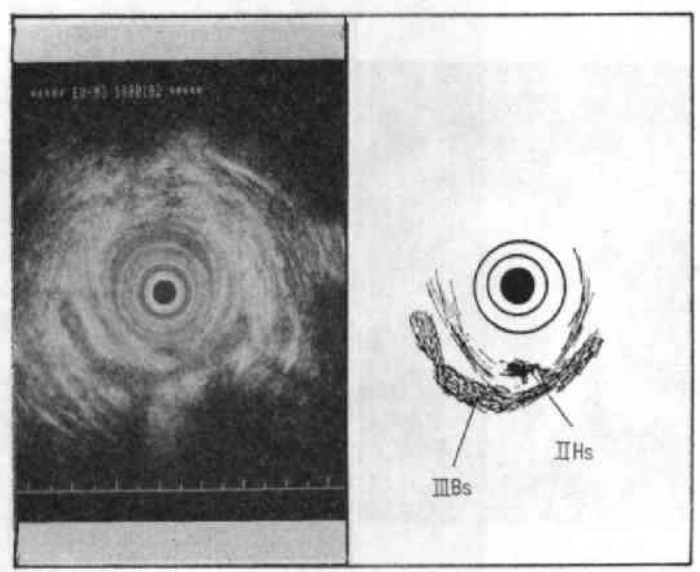

図 8 淀例 4 (術前)

される。

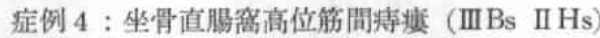

術前 6 時の位圆で外括約筋より内側に hypo-echoic

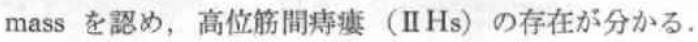
そしてさらに後方には馬崹形の hypo-echoic massを認 め, 坐骨直腸窝痔瘦 (IIIBs) む存在していることが分か る. 従って総合鳈は IIIBs II Hs となる（図 8).

術後 1 力月・術後 2 力月 IIIBs II Hs の術前診断て 括的觔温存術を施行した。 術後, 触診では異常を認めな かったが，血液検查で持続的な白血球上昇を認めた。 そ のため術後 1 力月に, 运音波検查を施行したところ, 肛 門の 8 時から10時にかけて, ドレナージ不十分による坐 骨㨁腸窝の馬蹄形の病変の残存を認めた (困 9 ). そこ で抗生剂を投与し, 術後 2 力月目に超音波検查を施行し たところ，8時から10時にかけての残存病変が消失して いる(図10).

3. 再発例 


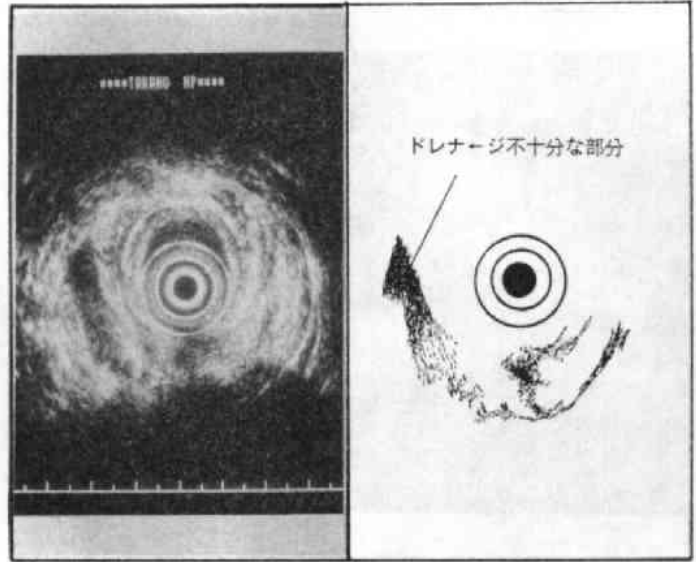

図 9 症例 4 (術後 1 力月)

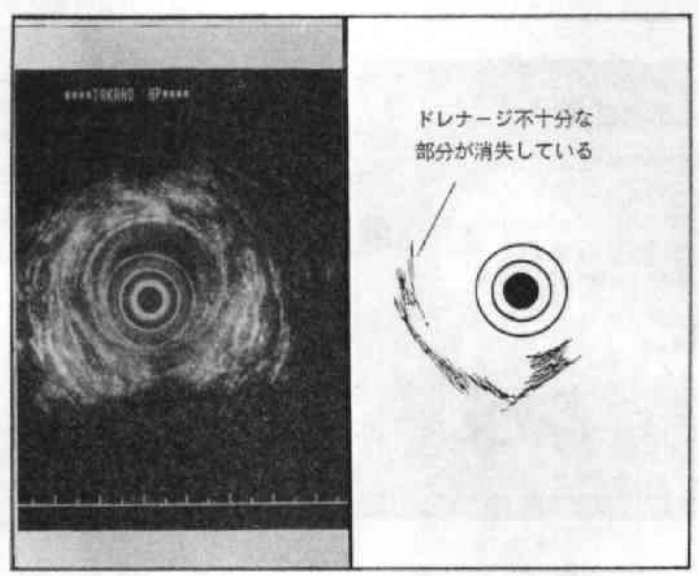

図 10 症例 4 （術後 2 力月）

低位筋間病変術後再発例 2 例, 坐骨直腸窝病変術後再 発例 4 例, 骨盤直腸窝病変術後再発例 1 例 (主病変部を 指す) の計 7 例の再発例に超音波検査を施行した。

筋間病変の再発例の場合, 避音波画像上, 病変は術前 の䢔音波画像や経過順調例と同様に hypo-echoic に措 出され，超音波検查による再発の診断は困難である。そ れに対し, 坐骨直膘窝病变術後再発例 4 例と骨盤直腸窝 病変術後再発例 1 例の計 5 例の場合, 術前に見られる cystic pattern と同様に描出され, 経過順調例の迹音波 画像とは明らかに異なり, 再発の診断を下すのは可能で ある.

症例 6 : 低位筋間痔萑（II Ls）

術前術前の超音波検查で11時と12時の間の皮下外括約 觔内倒に hypo-echoic mass を珰わ，診断は低位筋間

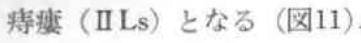

街後 1 力月くり拔き半䒽鎖術を施行したが, 術後 1 カ月より，くり拔き部の末梢例より膿排出を認めた，超

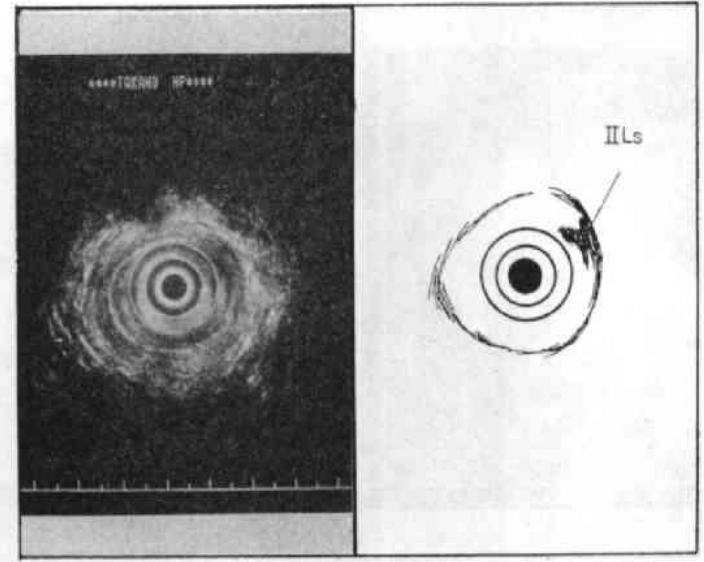

図 11 症例 6 (術前)

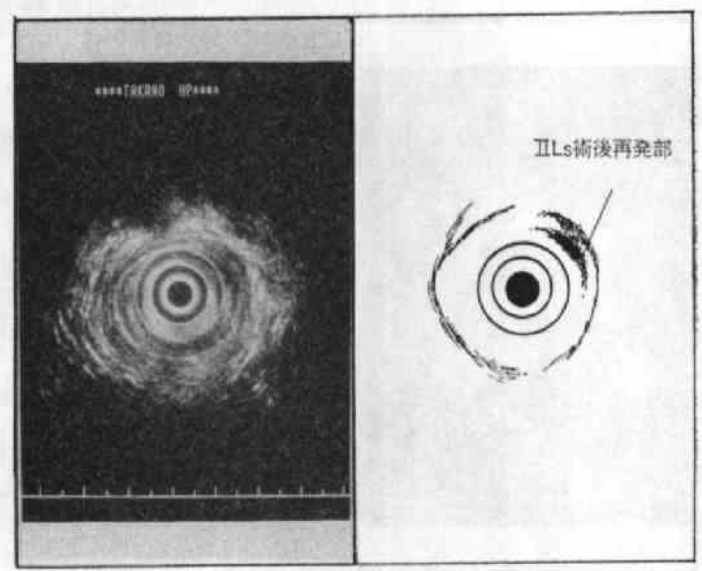

图 12 症例 6 (街後 1 力月)

音波画像で, 術前と同様に11時加ら12時の間に hypo-

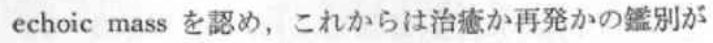
困難である(図12).

症例 7 : 坐骨直榪窝高位舫間痔瘦（IIIBs II Hs)

街前術前では超音波画像上，外括約觔内において 6

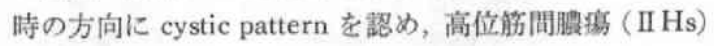
が存在していることが分かる.さらにその後方の Cour. tney's space に同様の cystic pattern を認め, 坐骨直 腸窝胀瘜 (IIBs) \&存在している. 従って術前診断は IIIBs II Hs となる (図13).

術後 1 力月 括約觔温存術後 1 力月で, 術創は順調に 経過し, 肉眼的には瘦痕に近い状热になった.しかし術 後より白血球上异が続くため, 超音波検查を施行した. その結果, Courtney's space に術前と同様に cystic pattern を羿め, 再発と䛦断した (図14).

4. 括約筋断裂による括䄪不全

超音波検查により括約觔が描出できることを利用し， 


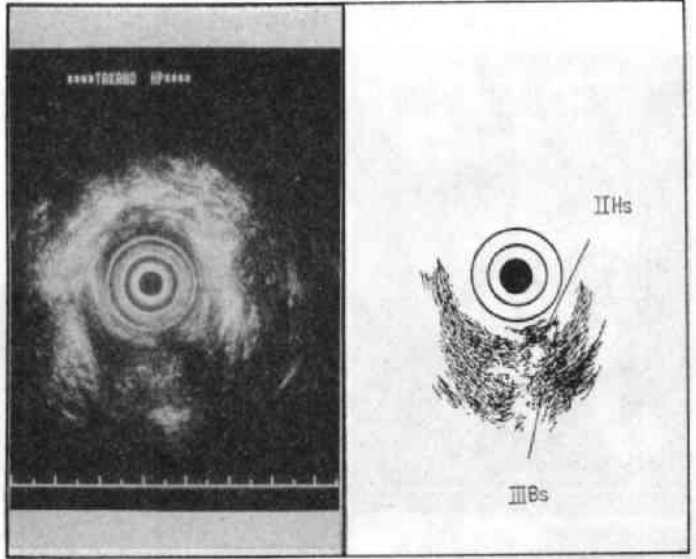

図 13 症例 7 (術前)

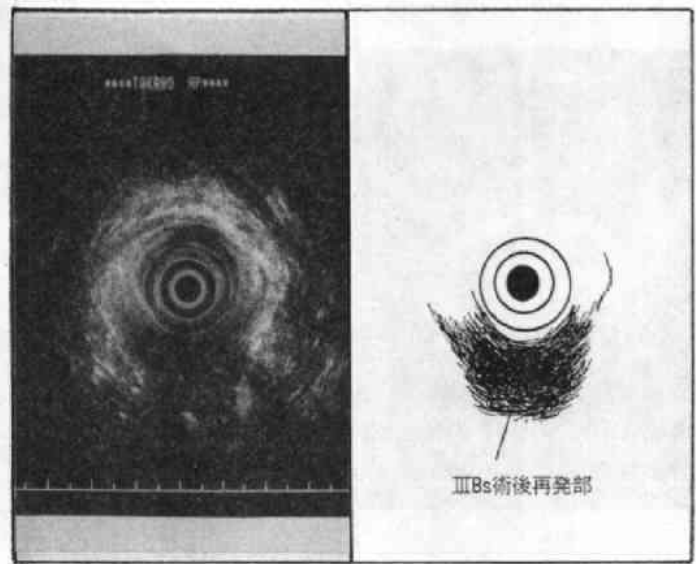

図 14 症例 7 (術後 1 力月)

括約不全の症例において括約筋の断裂の状態を調べるこ とができる，また術後は括約筋の修復の良否を調へるこ とが可能となる.

症例 8 : 術後括約不全

術前 5 年前に側方の痔瘦で他院にて根治術を施行し たが，それ以後 soiling が見られるようになり，当院に 来院した症例である.超音波椧查を施行すると， 2 時か ら 4 時にかけて皮下外括約筋が断裂している（図15）.

術後 1 力月 断裂した皮下外括約䇨と内括約筋の断端 を露出させ綪合した，術後1 カ月目の超音波画像で， 2 時から 4 時にかけて術前には認められなかった外括約管 が認められる(図16).

\section{III. 考察}

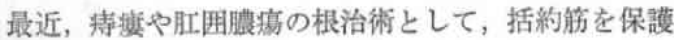
あるいは温存する術式が工夫され，嵒床的に応用される ようになってきて㧍りここの傾向は最近ますます強くな

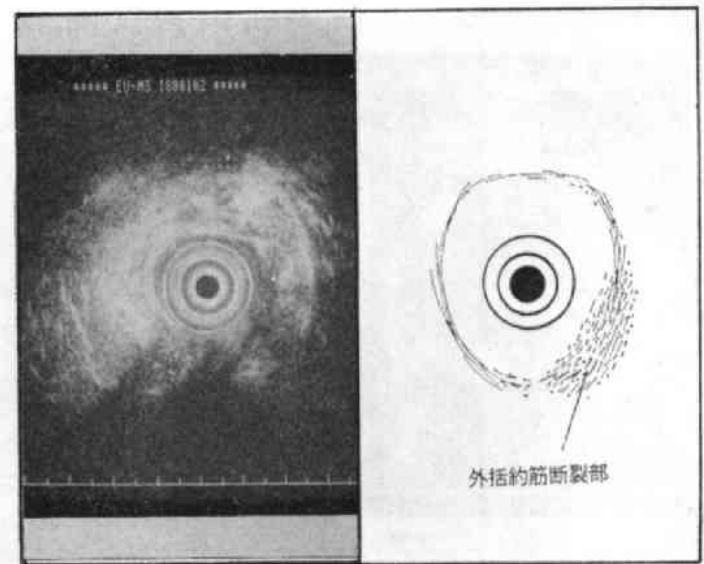

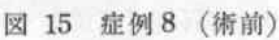

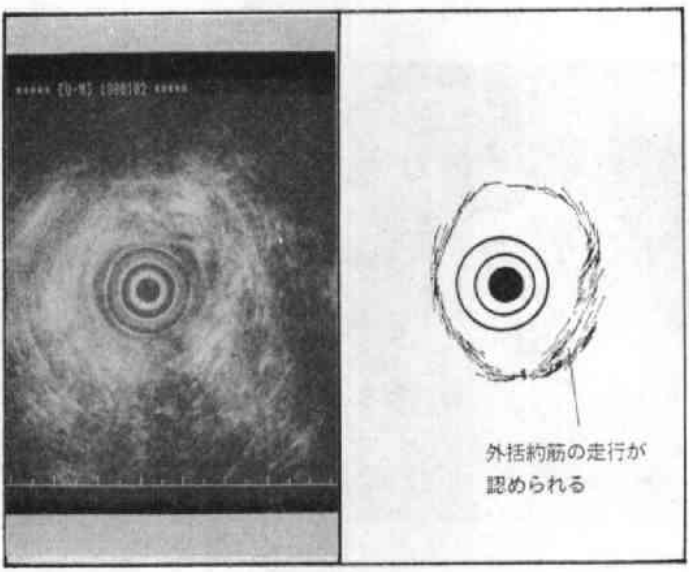

図 16 定例 8 (術前)

ってきている.

しかしこの術式の場合, 痔瘦あるいは肚囲膿癔の主病 変を処理した部分は括約筋内に㩊れてしまうことが多 く，術後は主として触喑により経過を観察していくこと になる、ところが術值後には, 疼痛のため触診によって くまなく辕査することは不可能である。また術後しばら く経過した症例では, 創治瘦とともに硬結が加わり, 触 診困難となる。この点で, 疼痛が少なく短時間で肛門を くまなく精査可能で，写真として画像を残すことにより 検查終了後も再検討が可能である超音波検植法が有効で はないかと考え，試用してみた。

当初は，術前と同栐に術後も hypo-echoic mass とし て描出される症例が多く，判断に難渋した，しかし触骖 と血液検查を組み合わせ, 経過順調例の超音波画像を基 礎とし，これらのデーターを比较検討することによっ $\tau$, 経過順調例, 経過遷延例, 再発例間の鑑別が可能と なり，術後経過の判定が可能となった。またこの検查に 


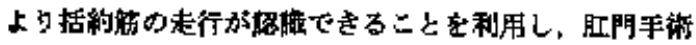

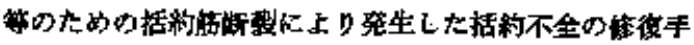

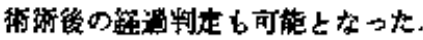

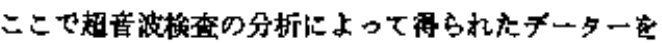

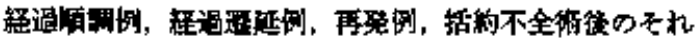
ぞれ礼分けて蒾心る。

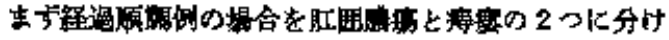

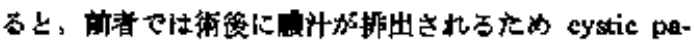

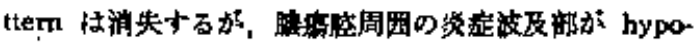

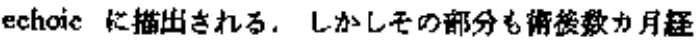

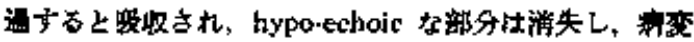

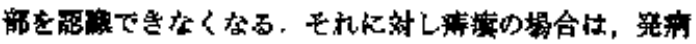

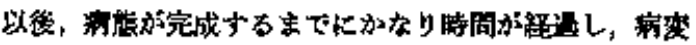

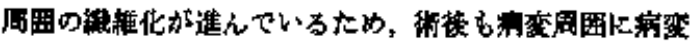

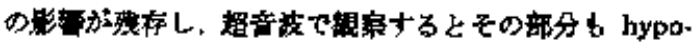
echoic mass $\varepsilon し て$ 描出

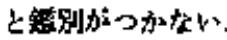

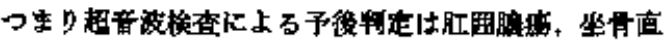

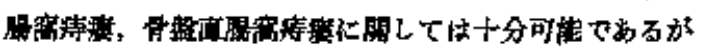

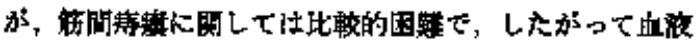

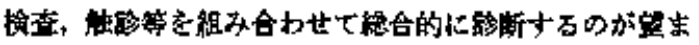
L.?.

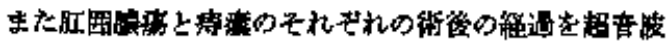
西你を通して対比分析することにより手修時期の沙いに

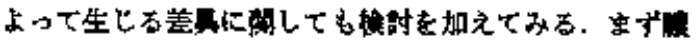

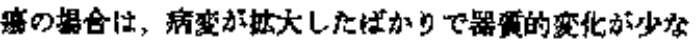

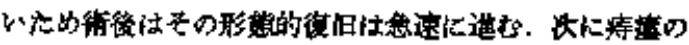

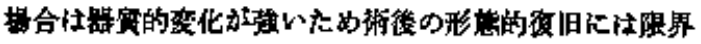

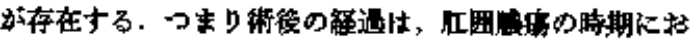

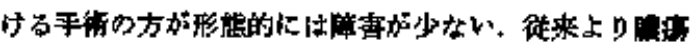

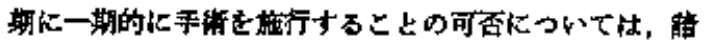

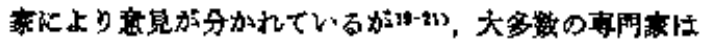

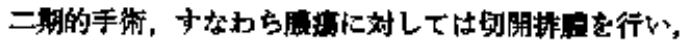

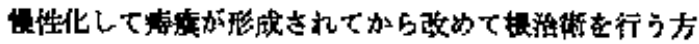
式党支持しているようである、この理由として性いるい ろかげられるが, primary abscess の同定が因篗である

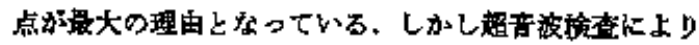

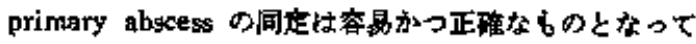

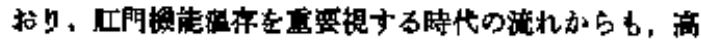

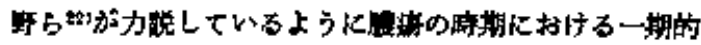

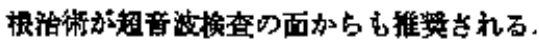

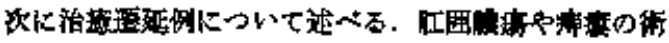

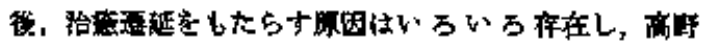

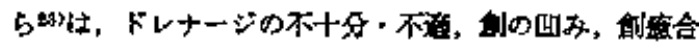

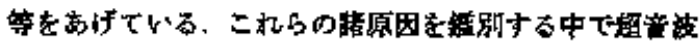

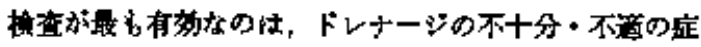

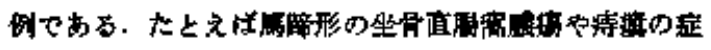

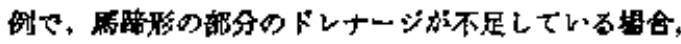

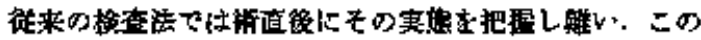
点，超音波换龺を行うと、この部分のドレナー沙不层を

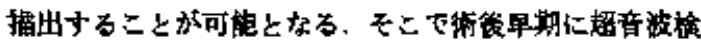

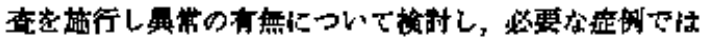

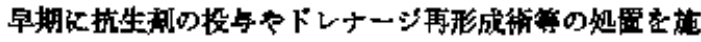

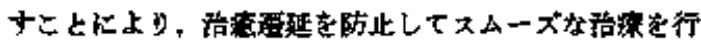
うことが可能となる。

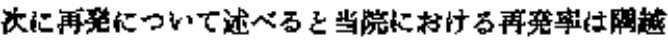
の㖽で 刀L $11 / 65(1.5 \%)$, IH : $3 / 84(3.6 \%)$, III : $5 / 74(6.8 \%)$, IV : 2/23 (9.5\%) 飞なって求り,

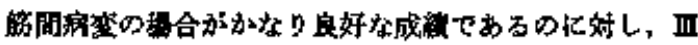

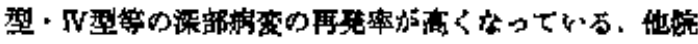

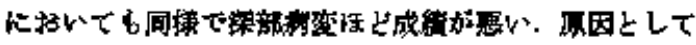

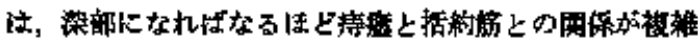

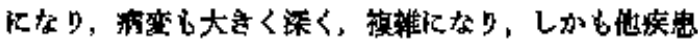
に起因することも多いことなとがあげられる，

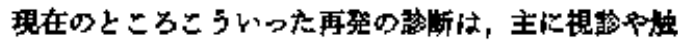

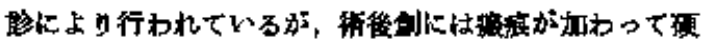

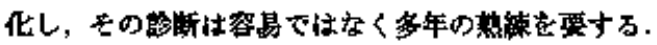

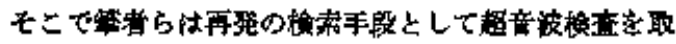

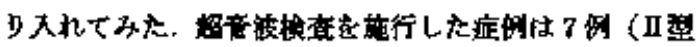

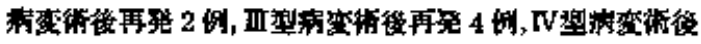

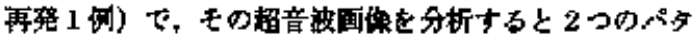
ーンド分けら和る、1つは hypo-echoic mass として描

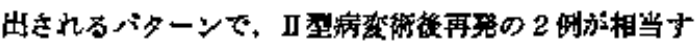
る. 2っ目社 cystic pattern にして措出されるバターン

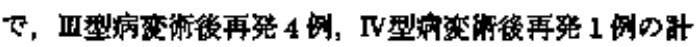

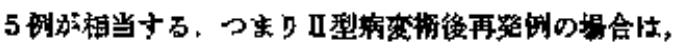

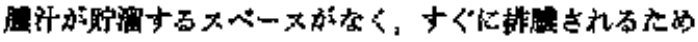
に招音波画像上 hypoechoic mass として描出され，

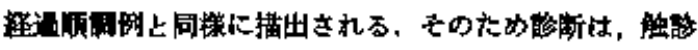

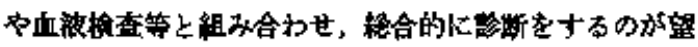

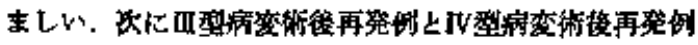

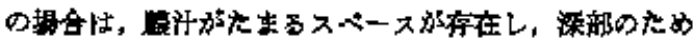

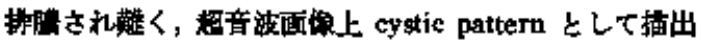

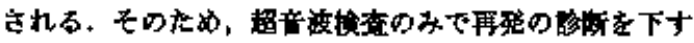
のし可伦であると思われる。

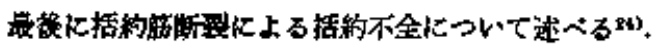

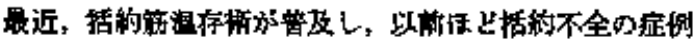

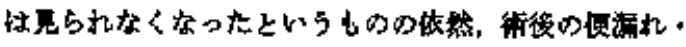

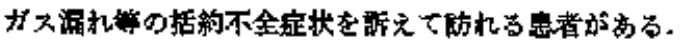

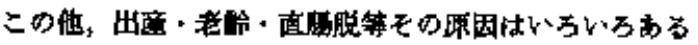

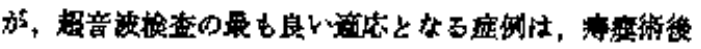

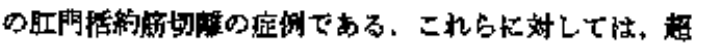




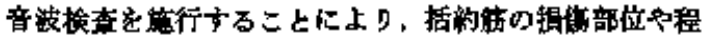

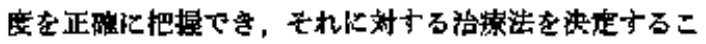
とができる.さらに衙後, 同じ手法により手術の成否を

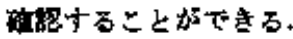

\section{文塑}

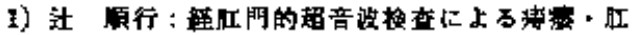

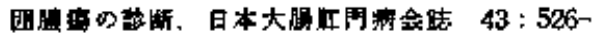
532,1990

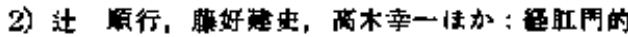

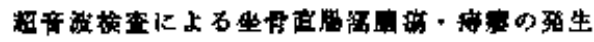

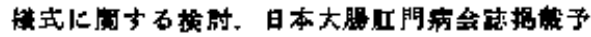
定

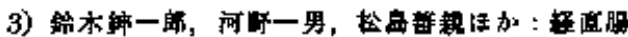

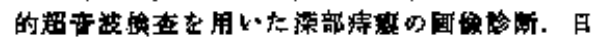

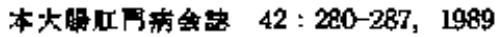

4) Parks AG : Pathogenesis and treatment of fistula-in-ano. $\mathrm{Br}$ Med $318: 463-469$, I961

5) Goligher JC: Surgery of the Anus, Rectum and Colon, 3rd ed, London, Bailliere, Tindall \& Cassel : 223-244, 1975

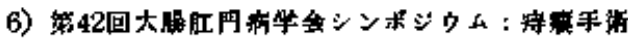

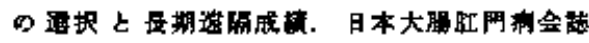
$40: 514-516,1987$

7) Hanley PH : Conservative, surgical correction of horseshoe abscess and fistula, Dis Colon Rextan 8: 364-368, 1965

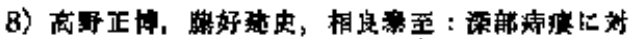

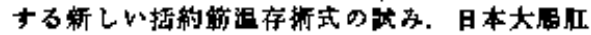
閒满会范 $36: 345-354$, 1985

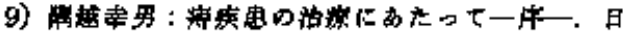

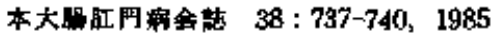

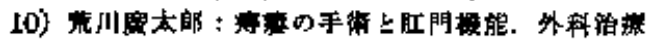
$34: 289-297,1976$

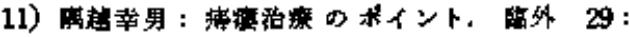
885-891, 1974

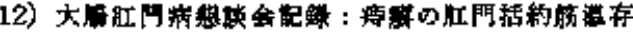

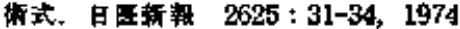

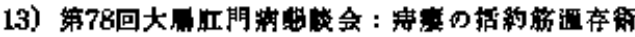

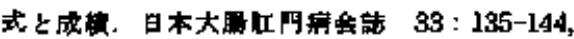
$1 \% 0$

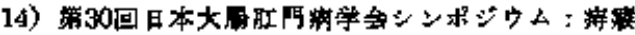

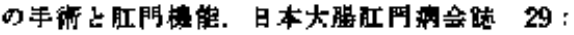
$136-142,1976$

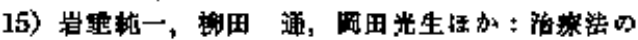

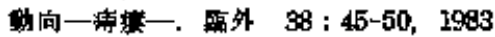

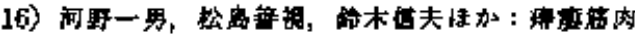

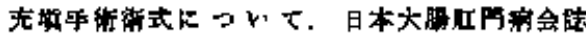
$38: 669-676,1985$

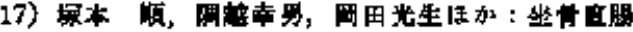

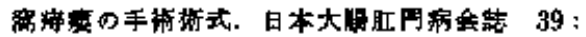
515,1986

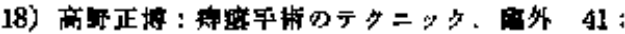
985-993, 1996

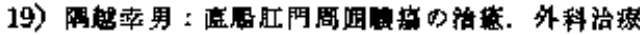
$49 \div 451-456, \quad 1983$

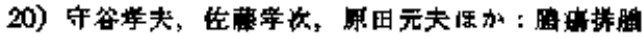

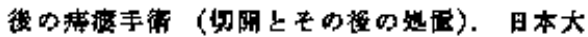

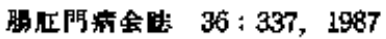

21) Lockhart-Mummery ME: Anorectal pro. blems : Treatment of abscess. Dis Colon Rectum $18: 650-651$, 1975

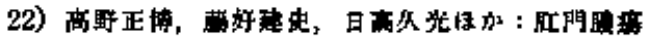

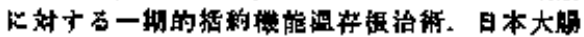
肚阿期会范 $40: 777-785,1987$

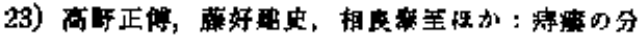

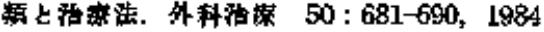

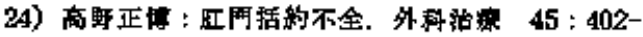
408,1981 


\title{
Usefulness of Transanal Ultrasonography for the Assessment of the Postoperative Course of Anal Diseases
}

\author{
Y. Tsuji*, T. Fujiyoshi, K. Takagi, M. Fujiyashi, M. Kawano, M. Hashimoto, \\ A. Hamada, N. Fujimoto, T. Sasaki and M. Takano \\ Coloproctology Center, Takano Hospital, Kumamoto \\ * The 2nd Dept of Surgery, Nippan Medical School, Tokyo
}

Since last May, we have been investigating anatonical features of anal diseases, especially of anal fistula using ultrasonography. We report here ultrasonographic features of anal diseases, perticularly in various postoperative condition.

The subjects are 27 postoperative patients who were opereted upon from May 1989 to June 1990 at our hospital, of whom 10 showed favourable, 5 showed delayed healing processes, 7 showed recurrence and 5 were cases operated for incontinence. The results were as follows:

1. Of the group with favourable progress, ultrasonographic evaluation was practicaliy valuable to assess the postoperative course of anal abscess and anal fistula of III and IV. While in the cases of intermuscular fistula, both of favourable progress and recurrence, the fistulous tract was imaged as hypa-echoic mass, and digital examination and hematological test were necessary to obtain more exact diagnosis of the fistula. 2. In the cases of insufficient drainage which caused delay of recovery, the lesion was so well imaged that the ultrasonography was of value. 3. In the cases of recurrence of intermuscular fistula, as mentioned atove, it was recommendable to evaluate it with comprehensive methods, but in the cases of III and IV, it was possible to diagnose the recurrence by ultrasonography alone as their images were figured out as cystic patterns. 4 . In the cases of incontinence due to the breakage of the sphincters, it was possible to confirm it by the ultraganography whether the sphincterplasty was satisfactory or not.

(平成 2 年11月 8 日要付) 